\title{
Kajian fungsi bridle line pada jaring insang dasar
}

\author{
Study of the function of bridle line on the bottom gill nets
}

\author{
AZWAR EGUH WAHYUDDIN*, EMIL REPPIE dan ISROJATY J. PARANSA \\ Program Studi Pemanfaatan Sumberdaya Perikanan, Fakultas Perikanan dan Ilmu Kelautan, \\ Universitas Sam Ratulangi, Manado 95115.
}

\begin{abstract}
Bottom gill nets that operated in the waters that have coral reefs would give impact on the coral, because the leader line of the nets touches the bottom of the sea. The use of bridle lines at the bottom part of gill net could minimize the damage of aquatic habitat. The purpose of this study was to compare the amount of uplifted coral cover, and the catch between nets with bridle lines and nets without bridle lines, as well as to identify the catch. The study was based on the experimental method; data was collected by operating six units of bottom gill nets for 10 trips in coastal waters of Kelurahan Sario Tumpaan, Manado Bay. Three units of nets using bridle lines and three other units without bridle lines. Data analysis was performed using a paired $t$-test. The results showed that the bottom gill nets with bridle lines had less impact on coral reefs than the nets without bridle lines. The fish species caught by the two types of nets were similar.
\end{abstract}

Keywords: bottom gill net, bridle line, coral reefs, habitat damage

\begin{abstract}
ABSTRAK
Jaring insang dasar yang dioperasikan di perairan berterumbu karang akan memberikan dampak kerusakan karang, karena tali pemberat jaring bersentuhan langsung dengan dasar perairan. Penggunaan bridle line pada bagian bawah jaring insang dasar diduga dapat meminimalkan kerusakan habitat dasar perairan. Tujuan penelitian ialah untuk membandingkan jumlah tutupan karang yang terangkat dan hasil tangkapan dari jaring yang menggunakan bridle line dengan jaring tanpa bridle line, serta mengidentifikasi hasil tangkapan. Penelitian ini didasarkan pada metode eksperimental. Pengumpulan data dilakukan dengan mengoperasikan enam unit jaring insang dasar dalam 10 trip di perairan pantai Kelurahan Sario Tumpaan, Teluk Manado. Tiga unit jaring menggunakan bridle line dan tiga unit lainnya tanpa bridle line. Analisis data dikerjakan menggunakan perbandingan nilai tengah contoh pengamatan berpasangan uji-t. Hasil analisis menunjukkan bahwa jaring insang dasar yang menggunakan bridle line memberi dampak kerusakan yang lebih kecil dibanding jaring tanpa bridle line. Jenis ikan hasil tangkapan dari kedua jenis jaring insang tersebut tidak berbeda.
\end{abstract}

Kata-kata kunci: jaring insang dasar, bridle line, terumbu karang, kerusakan habitat

\section{PENDAHULUAN}

Masalah kerusakan lingkungan bukan hanya diakibatkan oleh peningkatan jumlah penduduk, tetapi juga dari kenyataan bahwa pengeksploitasian sumberdaya alam yang ketersediaannya semakin terbatas, dilakukan oleh sebagian besar penduduk yang tidak memiliki alternatif sumber bahan makanan atau sumber pendapatan lain (Brown, 1977). Biasanya nelayan yang tidak memiliki pekerjaan alternatif, akan menggunakan segala upaya untuk mengeksploitasi sumberdaya

\footnotetext{
*Penulis untuk penyuratan; email: azwar_77@nokiamail.com
}

ikan sebanyak-banyaknya dalam waktu sesingkat mungkin (Nikijuluw, 1998), sehingga pada akhirnya akan terjadi kelebihan tangkap dan kerusakan lingkungan. Tetapi karena pemanfaatannya bersifat open access, serta setiap kelompok pengguna tidak memiliki tanggung jawab mengelola sumberdaya secara rasional, maka kerusakan ekosistem terumbu karang terus meluas. Praktek pengoperasian alat tangkap tradisional seperti bubu misalnya, biasanya bersifat merusak, dimana nelayan menutup alat tangkap dengan patahan karang hidup untuk menarik ikan target (Reppie, 2010). 